\title{
Thermal history of the Sabero Coalfield (Southern Cantabrian Zone, NW Spain) as revealed by apatite fission track analyses from tonstein horizons: implications for timing of coalification
}

\author{
Dariusz Botor $^{1}$ • Aneta A. Anczkiewicz ${ }^{2}$
}

Received: 27 June 2013 / Accepted: 9 March 2015 / Published online: 28 March 2015

(C) The Author(s) 2015. This article is published with open access at Springerlink.com

\begin{abstract}
Apatite fission track (AFT) central ages from Carboniferous (Stephanian) tonsteins of the Sabero Coalfield, NW Spain, range from $140.8 \pm 7.5$ to $65.8 \pm 8.1 \mathrm{Ma}$ (Cretaceous), with mean $c$-axis projected track length values ranging from 12.5 to $13.4 \mu \mathrm{m}$. Mean random vitrinite reflectance $\left(R_{\mathrm{r}}\right)$ of these samples ranges from 0.91 to $1.20 \%$, which can be translated into maximum palaeotemperatures of ca. 130 to $180^{\circ} \mathrm{C}$. All analysed samples experienced substantial post-depositional annealing. The considerably younger AFT ages compared to the depositional ages of the samples and $R_{\mathrm{r}}$ data indicate the certainty of the occurrence of at least one heating event after the deposition of strata. The unimodal track length distributions, the relatively short mean track length, and the rather low standard deviation (SD) $(1.0-1.6 \mu \mathrm{m})$ indicate a relatively simple thermal history that could be related to the post-Late Variscan heating event followed by prolonged residence in the apatite partial annealing zone (APAZ). Geological data combined with thermal models of AFT data indicate that Stephanian strata reached the maximum palaeotemperatures in the Permian period, which was therefore the major time of the coalification processes. The Permian magmatic activity was responsible for a high heat flow, which, with the added effect of sedimentary burial, could account for
\end{abstract}

Dariusz Botor

botor@agh.edu.pl

Aneta A. Anczkiewicz

ndstruzi@cyf-kr.edu.pl

1 Faculty of Geology, Geophysics and Environmental Protection, AGH University of Science and Technology, al. Mickiewicza 30, 30-059 Kraków, Poland

2 Institute of Geological Sciences PAS, Senacka 1, 31-002 Kraków, Poland the resetting of the AFT system. It appears that the faultrelated hydrothermal activity could have redistributed heat in areas of significant subsidence. Cooling occurred in the Triassic-Cretaceous times after a high heat flow Permian regime. A post-Permian maturation of the Stephanian organic matter is not very likely, since there is no evidence of a high Mesozoic burial that was sufficient to cause a significant increase in the palaeotemperatures. Finally, exhumation and associated erosion rates may possibly have been faster in the Tertiary, causing the present exposure of the studied rocks.

Keywords Sabero Coalfield · Cantabrian Zone - Apatite fission track analyses $\cdot$ Vitrinite reflectance $\cdot$ Thermal history $\cdot$ Pull-apart basin

\section{Introduction}

At the end of the Variscan orogeny, several small coal basins developed along major structural lines (Colmenero and Prado 1993; Colmenero et al. 2008) in what is now the Cantabrian Mountain region of Northern Spain. These basins are considered to have initially formed as small pullapart basins along strike-slip fault systems under a Late Carboniferous syn-orogenic transtensional regime (Julivert 1971; Reading 1975; Heward and Reading 1980; Wagner and Winkler-Prins 1985; Alonso et al. 1995; García-López et al. 1997, 2007; Bastida et al. 1999). Many of these basins in the Southern Cantabrian Zone (SCZ) were structurally controlled by a major E-W trending Variscan strikeslip fault system, named the Sabero-Gordon Line (Julivert 1971; Reading 1975; Heward and Reading 1980; Alonso et al. 1995; García-López et al. 1997, 2007; Bastida et al. 1999). Transpressional faulting and folding during the later 
stages of the Variscan orogeny at the end of the Carboniferous to the early Permian resulted in basin closure and inversion (Julivert 1971; Alonso et al. 1995; García-López et al. 1997, 2007; Bastida et al. 1999). This study examines the thermal history of one of these small basins $(\sim 12-15 \mathrm{~km}$ long and 3-4 km wide) located along the eastern end of the Sabero-Gordon fault line (Fig. 1) that contains the Sabero Coalfield (Heward and Reading 1980; Knight 1983; Knight et al. 2000). As little is known about the post-Variscan cooling history of this region (Carrière 2006; Grobe et al. 2010), we conducted an apatite fission track (AFT) thermochronometry study to define the thermal history of the Late Carboniferous (Stephanian) sediments of the Sabero Coalfield. The Sabero sedimentary sequence includes volcanic ash layers (tonsteins; Knight et al. 2000; Botor 2005) that provide precise time-temperature reference points in the stratigraphy, essential for accurate thermal history reconstruction.

\section{Geological setting}

The Sabero Coalfield (Fig. 1) is located in the south of the Cantabrian Zone, which represents the core of the Variscan Ibero-Armorican Arc. The study area constitutes part of the external zone of the Variscan orogenic belt in the NW part of the Iberian Peninsula (Marcos and Pulgar 1982) where two different successions can be recognized in relation to Variscan deformation (Julivert 1971; Marcos and Pulgar 1982): one pre-orogenic and one syn-orogenic. The preorogenic sequence comprises lower Palaeozoic siliciclastic rocks and Devonian carbonate and clastic formations. The syn-orogenic Carboniferous pile has been interpreted as a foreland basin sequence (Julivert 1971; Marcos and Pulgar 1982). Both successions were folded and thrust between Westphalian B and Stephanian times (Julivert 1971; PérezEstaún et al. 1988; Bastida et al. 1999). The main period of the Variscan deformation ended around $300 \mathrm{Ma}$, based on recent palaeomagnetic data that record the oroclinal bending of the Variscan Ibero-Armorican Arc (Van der Voo et al. 1997; Weil et al. 2001, 2010). This caused extension, crustal thinning, and strike-slip movements in the outer part of the orocline as well as compression and strong crustal thickening in the inner part (Gutierrez-Alonso et al. 2004) and was closely followed by delamination of the thickened lithospheric root and post-orogenic extensional collapse (Dallmeyer et al. 1997; Martinez-Catalan et al. 1997). The Variscan orogeny of Northern Spain was subsequently affected by the Alpine tectonics, which caused some structural reactivation (Alonso et al. 1995).

Over $2000 \mathrm{~m}$ of Stephanian A-B clastic sediments (conglomerates, sandstones, and shales with intercalated coal seams with tonsteins) were deposited unconformably on older Palaeozoic rocks in the Sabero Coalfield (Heward 1978; Knight 1983; Wagner and Winkler-Prins 1985; Knight et al. 2000; Colmenero et al. 2008). The Stephanian A strata contain about 20 coal seams and coal intercalations, whose thickness ranges from 0.3 to $2.0 \mathrm{~m}$, and the Stephanian B strata contain over 50 coal seams and coal intercalations, with thicknesses between 0.1 and $3.5 \mathrm{~m}$ (Knight 1983; Knight et al. 2000; Colmenero et al. 2008). Major folding of Stephanian sequences occurred in either Late Stephanian or Early Permian times (Reading 1975; Heward and Reading 1980; Wagner and Winkler-Prins 1985).

Small intrusions of sills and dykes, ranging in thickness from 1 to $15 \mathrm{~m}$, are exposed along the northern and southern boundaries of the Sabero Coalfield (Knight 1983; Ayllon 2003). These rocks, which are mainly dioritic to basic in composition, have geochemical affinities with the igneous rocks penetrating through the deposits of other Stephanian coalfields of the SCZ, as well as with Late Palaeozoic intrusive stocks occurring in other parts of the Cantabrian Zone (Munoz et al. 1985; Fernández-Suárez et al. 2000). Most plutonic stocks in the Cantabrian and northern Central Iberian Zones have a tonalite-granodiorite-monzogranite composition. They appear along with mafic to intermediate dykes and were intruded mainly between 295 and $285 \mathrm{Ma}$ (Early Permian), indicating that post-orogenic extension had begun by that time (Fernández-Suárez et al. 2000).

It is unclear whether Permian to Cretaceous sediments once covered the SCZ and were eroded later, since Permian to Cretaceous sedimentary rocks are not present in the SCZ (Lopez-Gomez et al. 2002). A former Permo-Triassic cover has been proposed (Alonso et al. 1995), and some Cretaceous sedimentation can also be expected, as this was a period of renewed extensional tectonic activity across the Iberian microplate that caused widespread regional subsidence (Lobato et al. 1984; Schwentke and Kuhnt 1992; Reicherter and Pletsch 2000). Cretaceous (Albian-Santonian) shallow marine sediments (calcarenites and mudstones) $150-800 \mathrm{~m}$ in thickness are known from the western end of the study area (Fig. 1) (Evers 1967). Towards the south, Palaeozoic sediments are covered by the Cretaceous and Tertiary basin-fill of the Duero Basin (e.g. Alonso et al. 1995).

Following extension, the Cantabrian Mountains underwent Cainozoic uplift related to the Alpine orogeny. Many Variscan faults (like the Sabero-Gordon fault) were reactivated along the southern border of the Cantabrian Zone (Alonso et al. 1995) including the steep $\left(65^{\circ}\right)$ south-dipping, E-W oriented La Llama fault (Fig. 1) that cross-cuts the coalfield and displaces the unconformably overlying Cretaceous rocks in the west. During its latest movement, this fault acted as a thrust plane, producing a downthrown displacement of about $400 \mathrm{~m}$ to the north (Evers 1967; Knight 1983; Knight et al. 2000). 


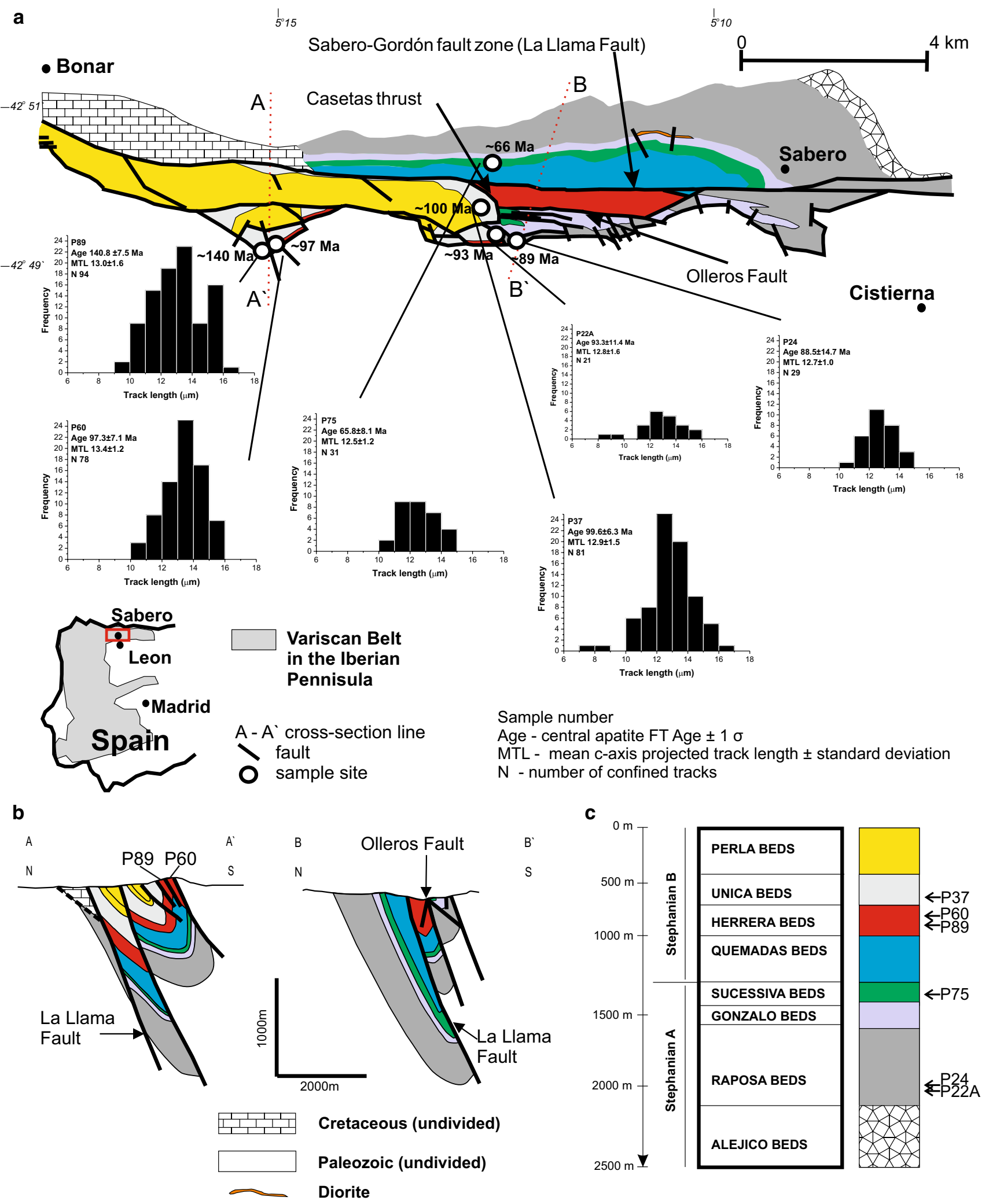

Fig. 1 a Geological sketch map of the Sabero Coalfield with AFT data, b geological cross sections of the Sabero Coalfield, and c sedimentary sequence showing the maximum thickness of the coal-bearing formations within the basin, and stratigraphic locations of sam- ples (all geological information for $\mathbf{a}-\mathbf{c}$ are based on modified data from Knight 1983; Alonso 1989; Knight et al. 2000; Ayllon 2003; Colmenero et al. 2008) 


\section{Previous studies related to thermal history of the study area}

In the SCZ, the Stephanian coal-bearing basins are distributed along deep-reaching strike-slip faults formed as a consequence of transtensional movements that migrated westward with time during the late stages of the Variscan orogeny (Aller et al. 2005; Colmenero et al. 2008). As the Stephanian sedimentary rocks in the basins generally have a higher coal rank than older Palaeozoic sediments in the same region, it has been suggested that the local magmatism (sills and dykes, volcanism) increased thermal maturation (Aller et al. 2005; Colmenero et al. 2008), producing a coal rank of up to anthracite level (above $2.0 \% R_{\mathrm{r}}$ ). In the Cinera-Matallana Coalfield (14 km west of the Sabero Coalfield), where the coal ranks are higher $\left(R_{\mathrm{r}}\right.$ up to $2.6 \% ; R_{\mathrm{r}}$ gradients are also higher), the average palaeogeothermal gradient during the Early Permian has been calculated as $85^{\circ} \mathrm{C} / \mathrm{km}$ with a heat flow of $150 \mathrm{~mW} / \mathrm{m}^{2}$ (Frings et al. 2004), although Mendez (1985) estimated a lower palaeogeothermal gradient of $60-70{ }^{\circ} \mathrm{C} / \mathrm{km}$, similar to other Stephanian coal basins across the Cantabrian Zone (Ayllon et al. 2003). Heat transfer by magmatism and related hydrothermal activity could have resulted in very high geothermal gradients and heat flow values (even over $100-160 \mathrm{~mW} / \mathrm{m}^{2}$ ), as seen in the coalfields of the Massif Central, France (Copard et al. 2000), Cinera-Matallana Coalfield, Spain (Frings et al. 2004), Bohai Basin, China $(\mathrm{Hu}$ et al. 2001), or the eastern Alps (Sachsenhofer 2001). Recent work on clay minerals in mudstones from the Cinera-Matallana Coalfield (Frings and Warr 2012) has revealed a complex mineralization history related to localized igneous and hydrothermal activity associated with strike-slip faulting. Peak temperatures (up to ca. $300{ }^{\circ} \mathrm{C}$ ) are found in areas of high fluid flow, with the hot hydrothermal growth of well-crystallized clay minerals occurring both prior to and synchronous with the Late Carboniferous/Early Permian folding and faulting of the sedimentary sequence (Frings and Warr 2012). The Sabero Coalfield is characterized by a moderate coal rank, and this suggests that any hydrothermal effects would not have been as intense as in other basins (Ayllon et al. 2003; Ayllon 2003; Knight et al. 2000; Botor et al. 2009; Botor 2012). The vitrinite reflectance values in the Sabero Coalfield are in the range of $0.8-1.8 \%$ (i.e. $1.2-1.8 \%$ as reported by Knight et al. 2000; 0.92-1.5\% by Colmenero et al. 2008; 0.8-1.5\% by Botor 2012). Samples with much higher values can be found (e.g. $3.96 \% \mathrm{Rmax})$ in rare cases, mostly in close association with sills (Botor et al. 2009). Estimated geothermal gradients of $52{ }^{\circ} \mathrm{C} / \mathrm{km}$ (Botor 2012) are lower than those at other Stephanian basins (Mendez 1985; Frings et al.
2004; Ayllon et al. 2003) and in the Palaeozoic basement (c. $35{ }^{\circ} \mathrm{C} / \mathrm{km}$; Brime et al. 2001).

Aller et al. (2005) argued that increased heat flow due to hydrothermal-fluid circulation was the last important thermal episode in the SCZ, facilitated by pathways along faults. As a consequence, the effects of this episode are irregularly distributed within the basins (Brime et al. 2001; Aller et al. 2005). Fluid inclusion results confirm that there was fracture-controlled fluid flow along thrusts and/or strike-slip faults (Gasparrini et al. 2003, 2006; Ayllon et al. 2003). The porosity and degree of compaction of the Stephanian sediments also likely to have played an important role in the coalification process, since relatively uncompacted and uncemented sediments would have facilitated fluid circulation (Duddy et al. 1994). Therefore, any related fluid activity that may reflect anomalous thermal gradients can be expected to have left an imprint upon the Stephanian clastic deposits and coals, either during or after their deposition (Frings et al. 2004; Botor 2012). Moreover, the abundance of hydrothermal mineralization and ore deposits in the Palaeozoic rocks (mainly in Carboniferous) related to regional faults constitutes the important metallogenic feature of the SCZ (Luque et al. 1990). Mineralization took place in Permian times and was associated with an extensional stress regime with a fluid temperature range of 100-300 ${ }^{\circ} \mathrm{C}$ (e.g. Gómez-Fernández et al. 2000; Ayllon et al. 2003; Gasparrini et al. 2003). The fluid event was probably related to a thermal peak in the Latest Stephanian and the Early Permian times, when oroclinal bending was associated with crustal thinning as well as magmatism (Gutierrez-Alonso et al. 2004; Schneider et al. 2008).

In the Permian period, localized increases in heat flow occurred along the fault areas due to the proximity of heat sources (magmatic intrusions and local hydrothermal flow related to extensional development) (Aller et al. 2005). Hydrothermal events were more or less simultaneous with the increased heat flow related to the magmatism of the whole area (Bastida et al. 1999). This magmatism could have promoted hydrothermal-fluid migration, especially in the areas of deep-seated faults along the Sabero-Gordon line (Gómez-Fernández et al. 2000). Consequently, the metal-bearing fluids would have been associated with episodes of magmatism and remobilization of the crust occurring at the end of the Carboniferous times (e.g. GómezFernández et al. 2000) and in the Early Permian, which, therefore, could have influenced the Stephanian rocks. However, hydrothermal circulation, although highly probable, has not been confirmed by the presence of any diagnostic minerals or high concentrations of metal elements in the Sabero Coalfield, probably due to low concentrations of metals in some areas (Botor 2011).

The regional context of the AFT data in the Cantabrian Mountains has recently been summarized by Juez-Larré 
and Ter Voorde (2009, and references therein), who identified three main thermal episodes occurring at the regional scale following the intrusion of the Late Variscan plutons and their cooling in the upper crustal levels. The first two episodes involved heating related to the opening of the North Atlantic (Upper Jurassic-Early Cretaceous) and Bay of Biscay (Upper Cretaceous-Early Palaeogene). The third thermal episode involved cooling as a result of exhumation processes during the Palaeogene. Recent regional AFT studies show that the Cantabrian Mountains have experienced a long-term thermal history. Samples from the Variscan basement yield a large range of AFT ages from $247 \pm 27$ to $53.5 \pm 12.9 \mathrm{Ma}$ (Grobe et al. 2010; MartinGonzalez et al. 2012). In the CZ, detrital AFT dating results from Neo-Proterozoic and Palaeozoic sediments reveal that partial annealing conditions prevailed from as early as NeoProterozoic times (Carrière 2006). In the west of CZ, AFT results suggest that episodes of heating during the opening of the Bay of Biscay were followed by cooling during the Alpidic shortening and unroofing in the Palaeogene-Neogene times (Carrière 2006).

\section{Samples and methods}

Ten tonstein horizons occur in the Stephanian sediments of the Sabero Coalfield (Knight et al. 2000). Several samples were collected from these tonstein horizons, both from shallow coal mines and surface outcrops across the Sabero Coalfield area, initially to identify their petrological characteristics (Knight et al. 2000). Petrological and geochemical studies of these tonsteins have revealed that these pyroclastic horizons are mainly composed of kaolinite, quartz, feldspars (plagioclases) and accessory minerals, mainly zircon as well as apatite (Knight et al. 2000). They were most likely derived from a calc-alkaline rhyodacitic to rhyolitic eruptive source (Knight et al. 2000; Botor 2005). These tonstein layers are composed of altered, distal, air-fall volcanic ashes of common chemistry and origin (Knight et al. 2000), which means that they are an excellent material for applying the AFT method. From these samples, ten were chosen for applying AFT analyses and also for measuring the vitrinite reflectance on the co-occurring coal material.

As a dating method, AFT analysis is a technique used to investigate the low-temperature thermal history of rocks. Fission track thermochronology is based on the analysis of radiation damage trails ('fission tracks') in uranium-bearing, non-conductive minerals and glasses. It is routinely applied on apatite, zircon and titanite. Fission tracks are produced continuously throughout geological time as a result of the spontaneous fission of ${ }^{238} \mathrm{U}$ atoms. They are submicroscopic features that can be revealed by chemical etching. Crucially, fission tracks are semi-stable features that can self-repair (shorten and eventually disappear) by a process known as annealing, at a rate that is a function of both time and temperature. The extent of any track shortening (exposure to elevated temperatures) in a sample can be quantified by examining the distribution of fission track lengths (e.g. Gleadow et al. 1986; Donelick et al. 2005; Braun et al. 2008). Apatite fission tracks undergo partial annealing within the temperature range of $60-110 \pm 10{ }^{\circ} \mathrm{C}$ (in the case of fluoroapatite), which is known as the APAZ. Fission tracks are completely annealed at temperatures higher than $110 \pm 10{ }^{\circ} \mathrm{C}$ for $10 \mathrm{Ma}$ (e.g. Donelick et al. 2005; Braun et al. 2008). Some variations in annealing kinetics have been observed and attributed to differences in the chemical composition of apatites and the crystallographic orientation of the spontaneous tracks (e.g. Barbarand et al. 2003; Ketcham et al. 2007a, b).

Apatite crystals were separated using conventional crushing, sieving, and magnetic and heavy liquids separation techniques. Apatite grains were mounted in epoxy resin on glass slides and polished to expose grain surfaces. Spontaneous tracks were revealed by $5 \mathrm{~N} \mathrm{HNO}_{3}$ at $20{ }^{\circ} \mathrm{C}$ for $20 \mathrm{~s}$. Neutron fluence (flux) was monitored using CN5 uranium dosimeter glass. Thin flakes of low-U muscovite were used as external detectors. Samples together with age standards (Fish Canyon, Durango, and Mount Dromedary apatite) and CN5 standard glass dosimeters were irradiated with a thermal neutron nominal flux of $9 \times 10^{15} \mathrm{n} / \mathrm{cm}^{2}$ at the Oregon State University TRIGA reactor (USA). After irradiation, muscovite was etched in $40 \% \mathrm{HF}$ for $45 \mathrm{~min}$ at $20{ }^{\circ} \mathrm{C}$ to reveal the induced tracks. For AFT analysis, we used the external detector and $\zeta$ age calibration methods in order to determine the fission track ages (Hurford and Green 1983; Hurford 1990). Track counting and length measurement of the horizontal confined fission tracks and the etch pit diameter $\left(D_{\text {par }}\right)$ values were carried out by means of optical microscopy at $1250 \times$ magnification using a Nikon Eclipse E-600, equipped with a motorized stage, digitizing tablet, and drawing tube controlled by the FTStage 3.12 and FTStage 4.04 programs (Dumitru 1993). All quoted AFT ages are the central ages of Galbraith and Laslett (1993) $\pm 1 \sigma$ error. The degree to which individual AFT grain ages in a sample belong to a single population was assessed by a $P\left(\chi^{2}\right)$ statistic (Galbraith 1981). Values of $P\left(\chi^{2}\right)$ below $5 \%$ indicate a statistically significant spread in single grain ages and the presence of more than one population (e.g. Galbraith 1981, 1990; Galbraith and Laslett 1993). The crystals chosen for confined track measurements had a well-polished surface parallel to the $c$-axis. For each sample, as many confined track lengths (Gleadow et al. 1986) as possible were measured. The measured confined track lengths were corrected for their crystallographic orientation by applying the computer code HeFTy to the data set (Donelick et al. 1999; Ketcham et al. 2007a). Data analyses and age calculations were based on a Zeta value $\zeta$ 
CN5 of $351.02 \pm 7.91$ for CN5 (Table 1) and accomplished by using Trackkey 4.2 software (Dunkl 2002).

The mean random vitrinite reflectance $\left(\% R_{\mathrm{r}}\right)$ was measured of samples with coal material occurring with the same tonstein samples used for AFT analyses. The reflectance measurements were carried out on polished grain sections using an Axioskop-Opton microscope in reflected white light mode, using a $50 \times$ oil immersion objective, following

Table 1 Determination of personal mean zeta values, used for calculation of the apatite fission track ages

\begin{tabular}{|c|c|c|c|c|c|c|c|c|c|c|c|c|}
\hline IR code & Standard & $N_{\mathrm{c}}$ & $\rho_{\mathrm{s}}$ & $N_{\mathrm{s}}$ & $\rho_{\mathrm{i}}$ & $N_{\mathrm{i}}$ & $\rho_{\mathrm{d}}$ & $N_{\mathrm{d}}$ & Age $\pm 1 \sigma(\mathrm{Ma})$ & $P\left(\chi^{2}\right)(\%)$ & $\zeta \pm 1 \sigma$ & \\
\hline OR 1 & $\mathrm{FC}$ & 20 & 2.243 & 178 & 13.266 & 1053 & 10.34 & 4798 & $30.3 \pm 2.8$ & 49.98 & 307.52 & 25.88 \\
\hline OR 1 & DUR & 20 & 1.661 & 289 & 9.157 & 1593 & 11.34 & 5444 & $35.8 \pm 2.8$ & 99.92 & 293.85 & 19.75 \\
\hline OR $2 \mathrm{a}$ & DUR & 20 & 1.668 & 314 & 9.011 & 1696 & 9.90 & 4899 & $29.8 \pm 2.3$ & 34.65 & 360.20 & 23.47 \\
\hline OR $2 \mathrm{a}$ & MTD & 20 & 4.388 & 336 & 8.228 & 630 & 10.34 & 4899 & $95.3 \pm 7.7$ & 97.43 & 356.93 & 24.72 \\
\hline OR 2 & $\mathrm{FC}$ & 20 & 1.754 & 122 & 11.634 & 809 & 12.25 & 4798 & $32.5 \pm 3.5$ & 86.58 & 343.31 & 34.08 \\
\hline OR 2 & DUR & 20 & 0.890 & 165 & 6.787 & 1258 & 12.26 & 4798 & $28.3 \pm 2.7$ & 99.57 & 399.49 & 34.09 \\
\hline OR $1 b$ & DUR & 20 & 2.201 & 290 & 12.021 & 1584 & 9.78 & 4697 & $29.9 \pm 2.0$ & 100 & 351.52 & 23.69 \\
\hline OR 1 & DUR & 20 & 1.719 & 246 & 11.195 & 1602 & 11.34 & 5492 & $29.1 \pm 2.1$ & 100 & 361.42 & 25.87 \\
\hline OR 3a & DUR & 20 & 1.616 & 267 & 25.470 & 1577 & 10.20 & 4896 & $29.3 \pm 2.1$ & 100 & 364.55 & 25.36 \\
\hline OR 1a & $\mathrm{FC}$ & 20 & 1.414 & 195 & 9.267 & 1278 & 10.23 & 4913 & $26.5 \pm 2.1$ & 100 & 358.22 & 28.72 \\
\hline OR $1 b$ & $\mathrm{FC}$ & 20 & 1.539 & 213 & 9.899 & 1370 & 10.05 & 4822 & $26.5 \pm 2.0$ & 100 & 357.83 & 27.61 \\
\hline OR 3a & $\mathrm{FC}$ & 20 & 1.941 & 230 & 11.104 & 1316 & 10.55 & 5068 & $31.5 \pm 2.4$ & 100 & 303.24 & 22.76 \\
\hline OR 3 & DUR & 20 & 1.633 & 287 & 9.610 & 1689 & 11.23 & 5394 & $32.4 \pm 2.2$ & 100 & 329.95 & 22.29 \\
\hline OR 1 & MTD & 20 & 7.664 & 396 & 15.367 & 794 & 11.43 & 5490 & $96.2 \pm 6.2$ & 100 & 348.97 & 22.08 \\
\hline OR 1a & MTD & 20 & 6.527 & 388 & 13.000 & 773 & 11.22 & 5386 & $95.3 \pm 6.2$ & 100 & 353.24 & 22.63 \\
\hline OR 3 & MTD & 20 & 5.624 & 471 & 11.320 & 948 & 10.60 & 5091 & $89.2 \pm 5.3$ & 100 & 377.74 & 22.06 \\
\hline OR4 & DUR & 20 & 1.435 & 467 & 9.442 & 467 & 10.96 & 5729 & $29.0 \pm 3.9$ & 100 & 349.41 & 14.36 \\
\hline OR4 & DUR & 20 & 1.649 & 247 & 10.239 & 1534 & 11.88 & 5735 & $33.3 \pm 2.3$ & 98.96 & 349.30 & 25.79 \\
\hline OR5 & DUR & 20 & 1.446 & 225 & 10.579 & 1646 & 11.91 & 5738 & $28.4 \pm 2.9$ & 99.84 & 386.67 & 28.62 \\
\hline OR5 & $\mathrm{FC}$ & 20 & 1.424 & 132 & 10.024 & 929 & 11.05 & 5638 & $27.5 \pm 2.7$ & 99.63 & 356.14 & 34.06 \\
\hline OR6 & $\mathrm{FC}$ & 20 & 1.433 & 177 & 11.433 & 1411 & 11.64 & 5611 & $25.6 \pm 2.2$ & 91.81 & 383.11 & 31.73 \\
\hline OR6 & MTD & 20 & 5.371 & 325 & 11.173 & 676 & 10.86 & 5609 & $92.1 \pm 6.8$ & 99.96 & 380.96 & 26.32 \\
\hline OR7 & FC & 20 & 1.839 & 127 & 12.396 & 856 & 10.48 & 5031 & $27.3 \pm 2.7$ & 99.89 & 325.78 & 22.08 \\
\hline OR7 & MTD & 20 & 5.940 & 344 & 12.329 & 714 & 9.74 & 5002 & $97.4 \pm 7.1$ & 99.89 & 365.17 & 27.87 \\
\hline OR 8 & DUR & 20 & 1.924 & 98 & 11.467 & 584 & 17.05 & 5120 & $30.7 \pm 3.4$ & 98.67 & 327.14 & 24.51 \\
\hline OR 8 & MTD & 20 & 9.204 & 110 & 20.499 & 245 & 17.21 & 5120 & $92.2 \pm 4.7$ & 99.97 & 357.48 & 29.81 \\
\hline OR 9 & $\mathrm{FC}$ & 20 & 1.918 & 137 & 15.712 & 1122 & 16.15 & 4813 & $29.8 \pm 3.1$ & 76.75 & 383.59 & 26.48 \\
\hline OR 9 & DUR & 20 & 1.776 & 69 & 13.485 & 524 & 16.03 & 4818 & $32.2 \pm 2.7$ & 99.92 & 345.19 & 38.72 \\
\hline OR10 & $\mathrm{FC}$ & 20 & 1.448 & 137 & 9.038 & 855 & 11.05 & 5403 & $31.1 \pm 3.0$ & 99.84 & 345.90 & 39.33 \\
\hline OR10 & DUR & 20 & 1.470 & 47 & 8.505 & 272 & 11.24 & 5403 & $34.1 \pm 5.5$ & 100 & 334.12 & 51.65 \\
\hline OR11 & DUR & 20 & 1.353 & 230 & 10.436 & 1774 & 10.79 & 5181 & $27.7 \pm 2.3$ & 99.66 & 343.78 & 47.88 \\
\hline OR11 & MTD & 20 & 5.259 & 150 & 10.412 & 297 & 10.85 & 5181 & $95.7 \pm 10$ & 100 & 362.97 & 36.77 \\
\hline OR12 & DUR & 20 & 1.281 & 246 & 9.725 & 1869 & 18.78 & 5681 & $28.4 \pm 3.4$ & 100 & 389.65 & 46.06 \\
\hline OR12 & $\mathrm{FC}$ & 20 & 2.329 & 100 & 18.257 & 784 & 18.73 & 5624 & $26.2 \pm 2.9$ & 99.97 & 353.98 & 25.39 \\
\hline OR13 & $\mathrm{FC}$ & 20 & 1.743 & 89 & 12.869 & 657 & 17.53 & 5085 & $26.3 \pm 3.2$ & 100 & 362.99 & 27.99 \\
\hline \multirow[t]{3}{*}{ OR13 } & MTD & 20 & 9.850 & 155 & 20.463 & 322 & 16.96 & 5085 & $92.2 \pm 7.6$ & 100 & 389.88 & 27.58 \\
\hline & & & & & & & & & Weighted mean zeta & 351.02 & & \\
\hline & & & & & & & & & Error & 7.91 & & \\
\hline
\end{tabular}

AFT age is a central age of sample $\pm 1 \sigma$ (error) (Galbraith and Laslett 1993) counted by using calibration method zeta $\pm 1 \sigma$ (error) (Hurford and Green 1983; Hurford 1990) and dosimeter (glass) CN5. Zeta value is $351.02 \pm 7.91$ (A. Anczkiewicz)

Age standards FC, fish canyon; DUR, durango; MTD, Mt. Dromedary; $N_{\mathrm{c}}$, number of apatite crystals; $\rho_{\mathrm{s}}$, density of spontaneous tracks $\left(\times 10^{5}\right.$ tracks for $\left.\mathrm{cm}^{-2}\right)$; $N_{\mathrm{s}}$, number of counted spontaneous tracks; $\rho_{\mathrm{i}}$, density of induced tracks on external detector $(\mathrm{mica})\left(\times 10^{5}\right.$ tracks for $\left.\mathrm{cm}^{-2}\right)$; $N_{\mathrm{i}}$, number of counted induced tracks; $\rho_{\mathrm{d}}$, density of induced tracks on external detector $\left(\times 10^{5}\right.$ tracks for $\left.\mathrm{cm}^{-2}\right) ; N_{\mathrm{d}}$, number of counted tracks. $P\left(\chi^{2}\right)(\%)$, probability homogeneity apatite population were showed by the test agreement $\chi^{2}$ value (Galbraith 1981) 
the usual International Committee for Coal and Organic Petrology (ICCP) procedures (ISO 7404-5 1994). The vitrinite reflectance is a time-temperature indicator governed by a kinetic response (Sweeney and Burnham 1990). Vitrinite reflectance continues to increase progressively with increasing temperature, allowing maximum palaeotemperatures to be directly estimated (e.g. Barker and Pawlewicz 1994; Sweeney and Burnham 1990) in the range where the fission tracks in apatite are totally annealed and therefore where AFT data only provides minimum estimates. Arne and Zentilli (1994) managed to relate specific $R_{\mathrm{r}}$ values to the corresponding annealing of AFTs. They showed that reflectance values of $0.7 \%$ (for fluoroapatites) to $0.9 \%$ (for chlorine-rich apatites) are indicative of thermal histories that comprise heating to temperatures high enough to totally reset the AFT ages. Integration of the AFT analyses and vitrinite reflectance data allows the framework for a coherent thermal history to be established (e.g. Bray et al. 1992).

Thermal modelling of the analysed samples was performed using HeFTy software (Ketcham 2005). This program uses induced data (such as AFT ages, confined track lengths, and etch-pits measurements) to define 'acceptable' time-temperature paths that pass baseline statistical criteria and also conform to a possible set of user-defined geological criteria (Ketcham 2005). This is a numerical search routine based on a data-driven approach using Monte Carlo methods. Thermal histories were modelled using the multi-kinetic model (Ketcham et al. 2007b), and $D_{\text {par }}$ values were used as kinetic parameters. The model $c$-axis projected length and $c$-axis projection were used (Ketcham et al. 2007b), and the default initial mean track length was calculated from $D_{\text {par }}$ values. Randomly generated thermal histories predicted the AFT age and length parameters and compared them to the measured data. Time-temperature $(t-T)$ paths were statistically evaluated and categorized by a 'goodness of fit' (GOF) value in which a 'good' result corresponds to a value of 0.5 , an 'acceptable' result corresponds to a value of 0.05 , and a GOF of 1 is the optimum (Ketcham 2005). For a comprehensive overview of fission track methods and their modelling techniques, the reader is referred to Donelick et al. (2005), Ketcham (2005), Ketcham et al. (2007b) and Braun et al. (2008).

\section{Results}

\section{Apatite fission track analyses}

The sample locations and their stratigraphic positions are given in Table 2 and Fig. 1. The results of the AFT analyses are presented in Tables 3 and 4 and Figs. 1 and 2. Three samples (P37, P60, and P89) out of six yielded enough apatite crystals for fission track analysis, including an adequate number of confined length measurements for thermal history modelling (Tables 3, 4; Figs. 1, 2). The other samples (P22A, P24, and P75) yielded fewer countable crystals but had similar central FT ages, which are indicative of a common thermal history (Tables 3, 4; Figs. 1, 2). The central AFT ages range from $140.8 \pm 7.5$ (Early Cretaceous) to $65.8 \pm 8.1 \mathrm{Ma}$ (Late Cretaceous), although four of the six samples yielded more restricted central AFT ages between 99 and 88 Ma (Late Cretaceous) (Table 3; Figs. 1, 2). Since all of the analysed samples had central AFT ages significantly younger than the Stephanian stratigraphic age of the layers from which they were collected (Table 3; Fig. 1), the samples must have experienced post-depositional temperatures in excess of $110^{\circ} \mathrm{C}$ (for at least $10 \mathrm{Ma}$ ), which leads to the resetting of the AFT system. A total of 334 lengths of horizontal confined spontaneous fission tracks were measured (21-94 per sample, Table 4). The mean track lengths obtained ranged from $11.5 \pm 1.4$ to $12.5 \pm 1.5 \mu \mathrm{m}$. All

Table 2 Location of the Sabero Coalfield tonstein samples

\begin{tabular}{|c|c|c|c|}
\hline Sample number & UMT coordinates $x, y$ & Tonstein reference level & Description of sample location \\
\hline P22A & $319,612,4,743,658$ & Level 11 & $\begin{array}{l}\text { Underground minę cross-cut 4E-5S, Pozo Sotillos; south side of coalfield, } \\
\text { fourth level of the minę; Raposa Beds }\end{array}$ \\
\hline P24 & $320,192,4,743,479$ & Level 12 & $\begin{array}{l}\text { Underground minę cross-cut 4E-5S, Pozo Sotillos; south side of coalfield, } \\
\text { fourth level of the minę; Raposa Beds }\end{array}$ \\
\hline P37 & $319,381,4,744,516$ & Level 40 & $\begin{array}{l}\text { Underground minę cross-cut } 4 \mathrm{~W}-14 \mathrm{~S} \text {, Pozo Sotillos; central area of coalfield, } \\
\text { south side; fourth level of the minę, below seam Capa } 3^{\mathrm{a}} \text {, Unica Beds }\end{array}$ \\
\hline P60 & $315,026,4,744,299$ & Level 32 & $\begin{array}{l}\text { From surface tip of Mina La Union, Veneros; west end of coalfield, south } \\
\text { side. Herrera Beds }\end{array}$ \\
\hline P75 & $319,462,4,745,762$ & Level 20 & $\begin{array}{l}\text { Underground minę cross-cut } 5 \mathrm{~W}-1 \mathrm{~N} \text {, Pozo Sotillos; north side of coalfield, } \\
\text { fifth level of the minę; within the coal seam Capa Sucesiva; Sucesiva Beds }\end{array}$ \\
\hline P89 & $314,709,4,744,329$ & Level 33 & $\begin{array}{l}\text { Surface exposure in surface minę workings in Veneros area; west end of } \\
\text { coalfield, south side. Herrera Beds }\end{array}$ \\
\hline
\end{tabular}

Further details are given in Knight et al. (2000) 


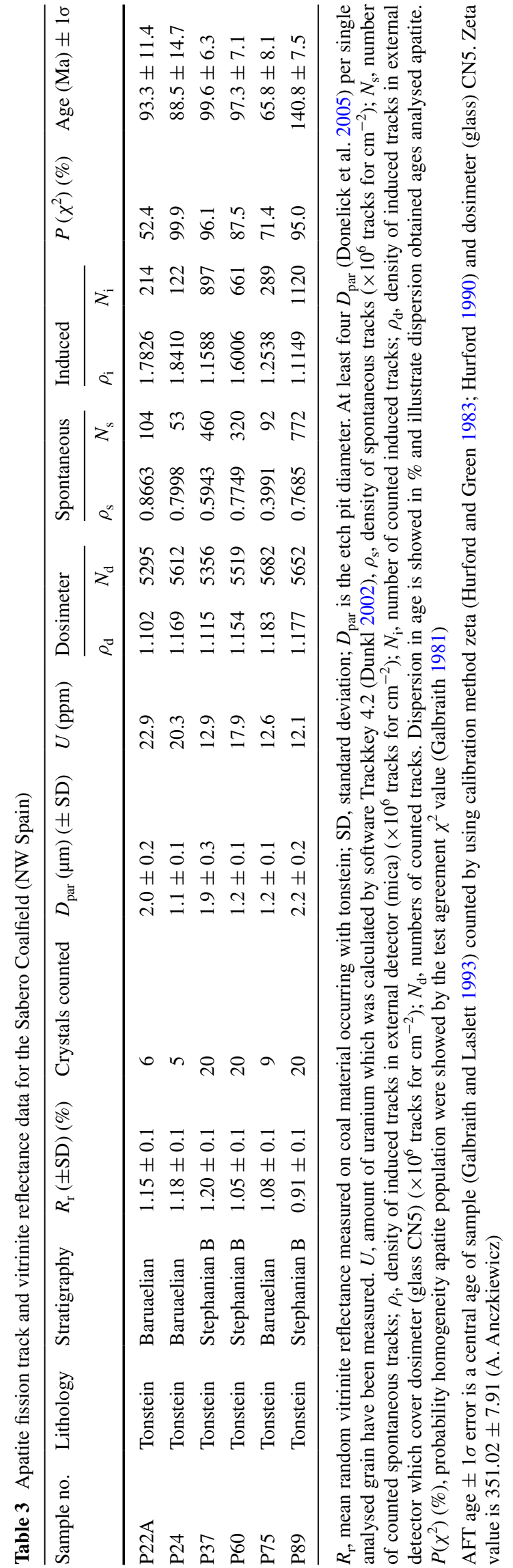

samples show a minor negative skewness between -0.05 and -0.93 , which is a tailing towards shorter track lengths indicating a simple gradual cooling, with the exception of sample P89 (Table 4). The SD values of track length ranged from 1.4 to $1.7 \mu \mathrm{m}$ (Table 4). The measured confined track lengths were corrected for their orientation to the crystallographic $c$-axis by applying HeFTy software to the data set (Table 4 ). The mean $c$-axis projected lengths changed to a distribution between $12.5 \pm 1.2$ and $13.4 \pm 1.2 \mu \mathrm{m}$. With the exception of P75, all the samples showed a negative skewness of between -0.02 and -0.67 (Table 4 ). The $\mathrm{SD}$ values of the $c$-axis projected track length ranged from 1.0 to $1.6 \mu \mathrm{m}$ (Table 4 ). These data show moderately slow cooling. The samples seem to have unimodal, narrow track length distributions, which could correspond to a cooling after a single heating event responsible for the shortening of tracks with no additional significant reheating events (Green 1986). Only sample P89 probably shows a mixed track length distribution (Fig. 1; Table 4), which could be related to a more complex thermal history. However, the SD of the distribution $c$-axis corrected track length in sample P89 is only $1.6 \mu \mathrm{m}$, which is not a convincing bimodal distribution. The samples P22A, P24, and P75 have an inadequate number of track length measurements (21-31, Table 4) for interpretation and thermal modelling.

The average etch pit diameter of tracks $\left(D_{\text {par }}\right)$ was measured for all samples (Table 4) as it is indicative of the annealing kinetics of apatites (Burtner et al. 1994; Barbarand et al. 2003; Donelick et al. 2005; Ketcham et al. $2007 \mathrm{a}, \mathrm{b})$. The mean $D_{\text {par }}$ values of the Sabero samples are in the range of $1.1 \pm 0.1$ to $2.2 \pm 0.2 \mu \mathrm{m}$ (Table 4 ), which generally correspond to fluoroapatites that are characterized by low resistance in annealing (Barbarand et al. 2003; Donelick et al. 2005). With the exception of two samples (P22A, P89) which show a positive skewness in the range 0.26-0.28, all other samples exhibit a negative skewness between -0.07 and -1.12 . The larger skewness values indicate a larger variation in etch pit size. In sample P22A, the smallest etch pit size is $1.65 \mu \mathrm{m}$, and the largest etch pit size is $2.43 \mu \mathrm{m}$. Sample P89 shows the smallest etch pit size of $1.76 \mu \mathrm{m}$ and the biggest of $2.87 \mu \mathrm{m}$ (Table 4 ).

\section{Vitrinite reflectance}

Mean random vitrinite reflectance $\left(R_{\mathrm{r}}\right)$ values in the analysed samples are in the range of 0.91-1.20\% (Table 3), which indicates a heating event after deposition strong enough to cause complete annealing of the fission tracks in apatite crystals from these strata (Arne and Zentilli 1994; Gallhager et al. 1998). According to different proposed methods, the measured $R_{\mathrm{r}}$ values were translated into maximum palaeotemperatures. Barker and Pawlewicz's (1994) method indicated temperatures of $126-151{ }^{\circ} \mathrm{C}$ for 
Table 4 Apatite fission track length and $D_{\text {par }}$ data for the Sabero Coalfield (NW Spain)

\begin{tabular}{|c|c|c|c|c|c|c|c|c|c|c|c|}
\hline $\begin{array}{l}\text { Sample } \\
\text { number }\end{array}$ & $n \mathrm{CT}$ & $\begin{array}{l}\text { CT mean } \\
(\mu \mathrm{m})\end{array}$ & $\begin{array}{l}\text { CT std } \\
(\mu \mathrm{m})\end{array}$ & CT skew & $\begin{array}{l}L_{\mathrm{c}} \text { mean } \\
(\mu \mathrm{m})\end{array}$ & $\begin{array}{l}L_{\mathrm{c}} \text { std } \\
(\mu \mathrm{m})\end{array}$ & $L_{\mathrm{c}}$ skew & $n D_{\text {par }}$ & $\begin{array}{l}D_{\mathrm{par}} \text { mean } \\
(\mu \mathrm{m})\end{array}$ & $\begin{array}{l}D_{\mathrm{par}} \mathrm{std} \\
(\mu \mathrm{m})\end{array}$ & $D_{\text {par }}$ skew \\
\hline P22A & 21 & 11.9 & 1.7 & -0.317 & 12.8 & 1.6 & -0.674 & 84 & 2.0 & 0.2 & 0.281 \\
\hline P24 & 29 & 11.7 & 1.6 & -0.935 & 12.7 & 1.0 & -0.110 & 116 & 1.1 & 0.1 & -0.073 \\
\hline P37 & 81 & 11.9 & 1.6 & -0.056 & 12.9 & 1.5 & -0.630 & 324 & 1.9 & 0.3 & -0.212 \\
\hline P60 & 78 & 12.5 & 1.5 & -0.816 & 13.4 & 1.2 & -0.382 & 314 & 1.2 & 0.1 & -1.128 \\
\hline P75 & 31 & 11.5 & 1.4 & -0.165 & 12.5 & 1.2 & 0.088 & 124 & 1.2 & 0.0 & -0.602 \\
\hline P89 & 94 & 12.2 & 1.7 & 0.135 & 13.0 & 1.6 & -0.022 & 376 & 2.2 & 0.2 & 0.265 \\
\hline
\end{tabular}

$n$ CT, number of measured confined tracks; CT mean, mean confined track length; std, standard deviation; skew, skewness of distribution relative to the mean value (measure of asymmetry of the distribution); $L_{\mathrm{c}}$ mean, mean track length after $c$-axis correction; $n D_{\text {par }}$, number of etch pit diameters measured; $D_{\text {par }}$ mean, mean etch pit diameter

burial-induced coalification or $158-176{ }^{\circ} \mathrm{C}$ for hydrothermally induced coalification (Fig. 3). Similar values also resulted from Sweeney and Burnham's (1990) method: $\sim 130-155^{\circ} \mathrm{C}$ for $10 \mathrm{Ma}$ of effective heating time or $\sim 145$ $170{ }^{\circ} \mathrm{C}$ for $1 \mathrm{Ma}$ of effective heating time.

\section{Discussion}

The Cretaceous AFT central ages (i.e. $140.8 \pm 7.5$ to $65.8 \pm 8.1 \mathrm{Ma}$ ) of the Carboniferous (Stephanian) analysed samples indicate post-formation resetting, and therefore at least one heating event exceeding the temperatures of $110{ }^{\circ} \mathrm{C}$ took place and/or there was a prolonged stay in the APAZ. Therefore, the inverse thermal modelling of samples P89, P60, and P37 was carried out (Fig. 3) by means of HeFTy software (Ketcham 2005; Ketcham et al. 2007b) in order to test the geological constraints against the thermochronological data set. Unfortunately, low track length counts in samples P75, P24, and P22a (31, 29, and 21, respectively; Table 4) precludes effective modelling and therefore the investigation of their post-sedimentation time-temperature $(t-T)$ paths. Details of the thermal modelling strategies for AFT data have been outlined by Ketcham et al. (2000) and Ketcham (2005).

In the analysed sample set, the beginning of the $t-T$ paths was defined by the estimated ground temperature $\left(25^{\circ} \mathrm{C}\right)$ during the time of the deposition of samples ( 302-306 Ma, Stephanian; Knight 1983; Knight et al. 2000), whilst their end was defined by the average presentday ground temperatures $\left(13{ }^{\circ} \mathrm{C}\right)$ at $0 \mathrm{Ma}$. In this setting, calculations were performed until the software calculated 100 good paths. Modelling was initially performed without any other limitations except for the ones mentioned above, but the resultant models were completely unsuccessful. There were no resulting paths at all that passed the baseline statistical criteria. Therefore, new models (Fig. 3) were constructed taking into account previous thermal history studies in the SCZ (García-López et al. 1997, 2007; Ayllon 2003; Ayllon et al. 2003; Frings et al. 2004; Aller et al. 2005; Frings and Warr 2012; Botor 2012), which indicated that the Late Carboniferous-Permian period was the main heating time. Vitrinite reflectance data were used to calculate the maximum palaeotemperatures (values $T_{\max } 2$ and $T_{\max } 3$ in Fig. 3) reached by the tonstein samples ( 130$180^{\circ} \mathrm{C}$ ). Based on this geological information, a new $t-T$ constraint was added to the modelling corresponding to a heating event in the Permian time (i.e. 299-250 Ma). The temperature range of this Permian constraint was drawn wider than the temperature calculated from $R_{\mathrm{r}}$, because the latter is not very precise (e.g. Barker and Pawlewicz 1994; Sweeney and Burnham 1990) (Fig. 3). Thermal history modelling, which included maximum temperature information from vitrinite reflectance data (Fig. 3), shows that most of this heating took place in the Permian and probably reached temperatures in the range of $130-180{ }^{\circ} \mathrm{C}$. However, the AFT data alone give evidence that temperature was higher than $110{ }^{\circ} \mathrm{C}$. The results of the thermal modelling of the Sabero Coalfield (Fig. 3) clearly indicated that the assumption about the latest Carboniferous-Permian heating allowed the best-fit calibration in all modelled samples (P37, P60, and P89). Previous studies applying different methods (clay minerals, fluid inclusions, vitrinite reflectance) in SCZ and the Sabero Coalfield have also led to similar conclusions (Bastida et al. 1999; Ayllon et al. 2003; Ayllon 2003; Frings et al. 2004; Aller et al. 2005; Colmenero et al. 2008; Botor et al. 2009; Botor 2012). Heating to temperatures of at least $110^{\circ} \mathrm{C}$ caused the complete resetting of AFT ages. After the maximum temperature climax, cooling generally occurred in the post-Permian period (Fig. 3), confirming that rocks near major faults like the Sabero-Gordon show evidence of late to post-Variscan total thermal resetting associated with sedimentary burial and circulation of thermal convection brines due to extension along the faults (Carrière 2006). Generally, the Stephanian rocks in the study area could have stayed at 
Fig. 2 Radial plots (Galbraith 1990) of the apatite samples from the Sabero Coalfield, showing single grain AFT ages for each sample (in Ma)

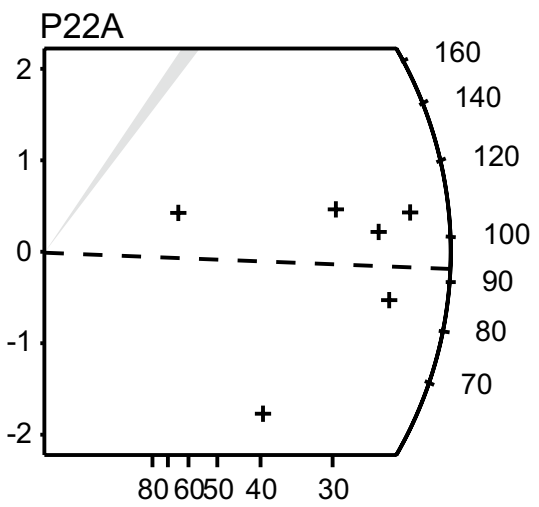

Rel. error [\%]

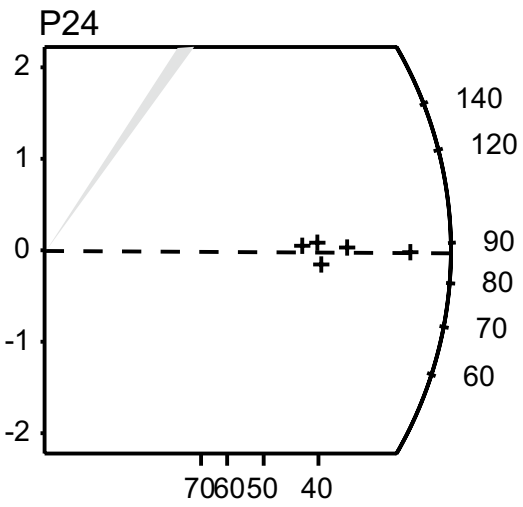

Rel. error [\%]

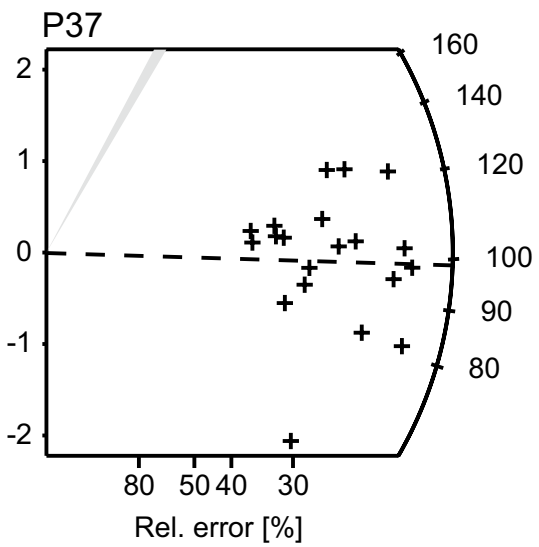

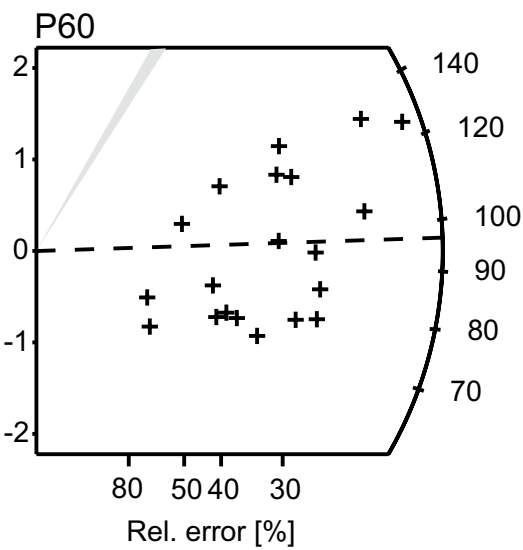
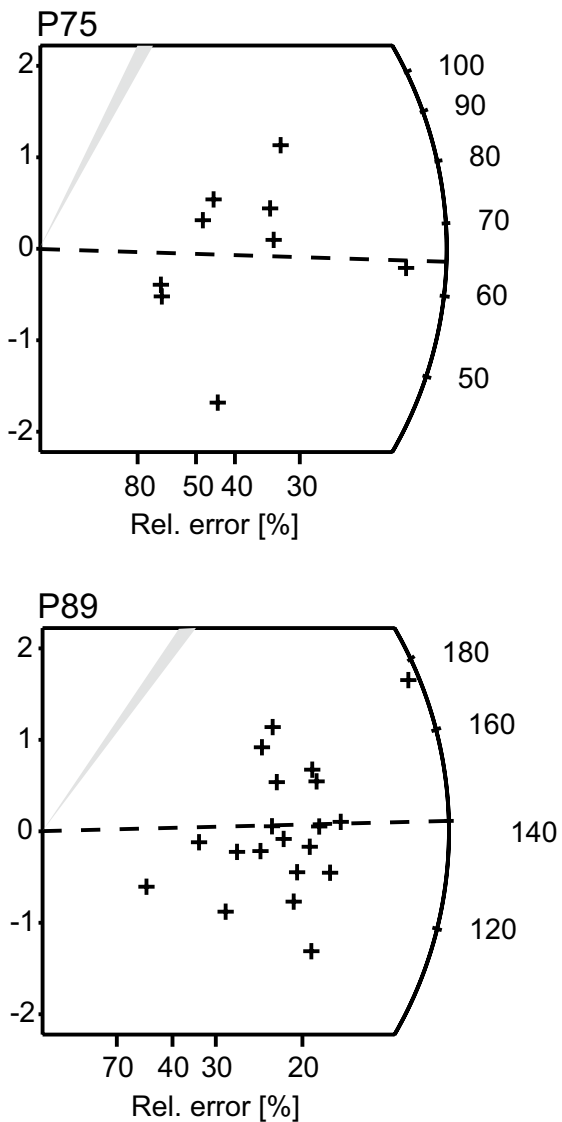

temperatures over $110{ }^{\circ} \mathrm{C}$ from the Early Permian to the Middle Triassic or even to the beginning of the Early Jurassic (Fig. 3). Cooling through the APAZ occurred between the Late Permian and Neogene (Fig. 3).

The cause of Permian heating event must have involved an increase in the geothermal gradient related to magmatic and hydrothermal activity, because the burial at normal geothermal gradients $\left(30{ }^{\circ} \mathrm{C} / \mathrm{km}\right)$ would have required at least $4.5-6 \mathrm{~km}$ of sedimentary sequence. Thicknesses of Stephanian deposits reach a maximum of $2 \mathrm{~km}$ (Knight et al. 2000), whilst several hundred metres of Permian strata were deposited in local basins, mainly in the northern part of the Cantabrian Mountains (Martinez-Garcia 1981; Suárez-Rodrigues 1988). However, the possibility cannot be excluded that both factors, the Early Permian sedimentary burial and the increase in the geothermal gradient due to magmatic and hydrothermal activity, could have contributed to heating in Permian times. In the vicinity of the Sabero Coalfield, there is no Triassic or Jurassic sedimentary cover (Suárez-Rodrigues 1988; Martinez-Garcia 1981; Lopez-Gomez et al. 2002). Subsequently, additional models were constructed for samples P89, P60, and P37 
Fig. 3 Thermal modelling results of samples P37, P60, and P897 from the Sabero Coalfield. Thermal modelling has been performed by HeFTy software (Ketcham 2005). Dark grey envelope of the $t-T$ paths with good fitting: light grey acceptable fitting (for details, see Ketcham et al. 2005, 2007a, b). A starting point $\left(\sim 304 \mathrm{Ma} ; 25^{\circ} \mathrm{C}\right)$ and the present-day point $\left(0 \mathrm{Ma} ; 13^{\circ} \mathrm{C}\right)$ were applied in the modelling. The inserted box for the Permian heating has maximum temperature range above value calculated from $R_{\mathrm{r}}$ in order to allow undisturbed $t-T$ modelling. $T_{\max } 1$, maximum palaeotemperature resulting from thermal modelling for the best fitting curve after inserting $t-T$ constraints (the calculated value is not precise over $\sim 110^{\circ} \mathrm{C}$ ); $T_{\max } 2$, burial maximum palaeotemperature (based on Barker and Pawlewicz 1994); $T_{\max } 3$, hydrothermal maximum palaeotemperature (based on Barker and Pawlewicz 1994); $R_{\mathrm{r}}$, mean random vitrinite reflectance; s.d., standard deviation; GOF, goodness of fit (Ketcham 2005). Further explanation in the text

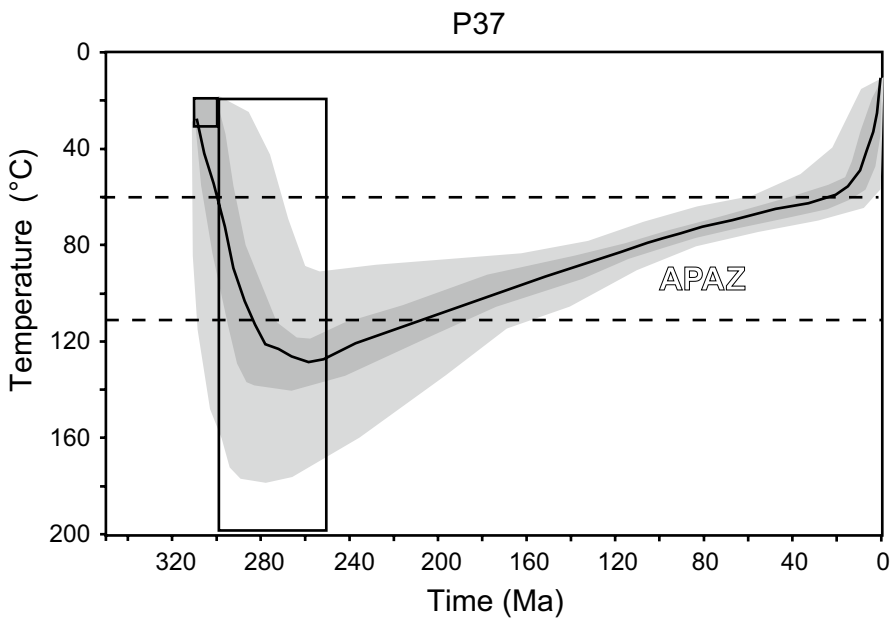

P37

$\mathrm{N}: 81$ confined tracks Age

Model $100.0 \mathrm{Ma}$ Measured 99.6 Ma GOF 0.98 Length Model $13.1 \mu \mathrm{m}$ Measured $12.9 \mu \mathrm{m}$ GOF 0.98

Rr $1.2 \%$ (s.d. 0.07)

$\operatorname{Tmax} 1130^{\circ} \mathrm{C}$

Tmax $2151^{\circ} \mathrm{C}$

Tmax2 $176^{\circ} \mathrm{C}$

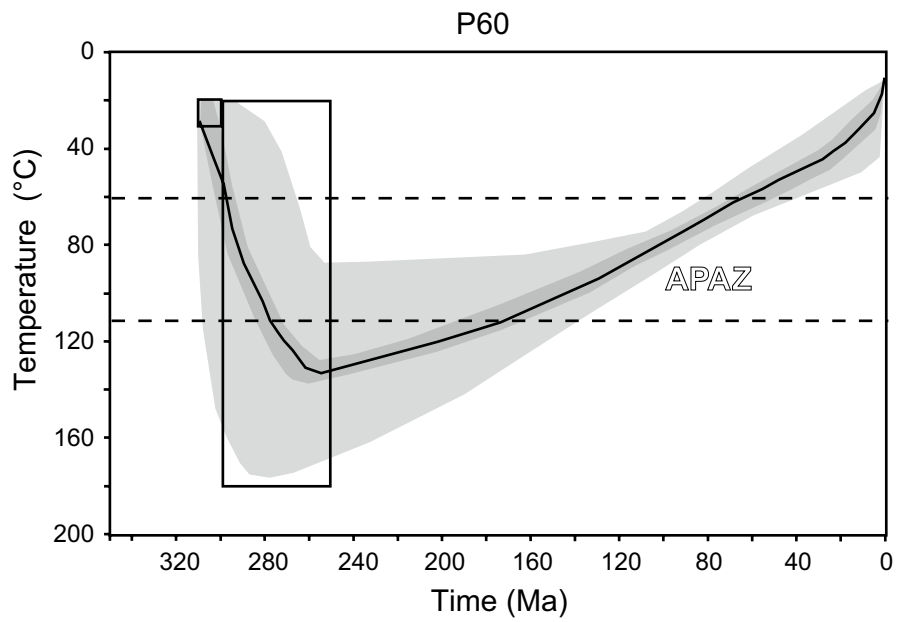

P60

$\mathrm{N}: 78$ confined tracks Age

Model $97.4 \mathrm{Ma}$ Measured 97.3 Ma

GOF 0.95

Length

Model $13.5 \mu \mathrm{m}$

Measured $13.4 \mu \mathrm{m}$. GOF 0.97

$\operatorname{Rr} 1.05 \%$ (s.d. 0.06)

Tmax $1132^{\circ} \mathrm{C}$

Tmax $2140^{\circ} \mathrm{C}$

Tmax3 $158^{\circ} \mathrm{C}$

P89

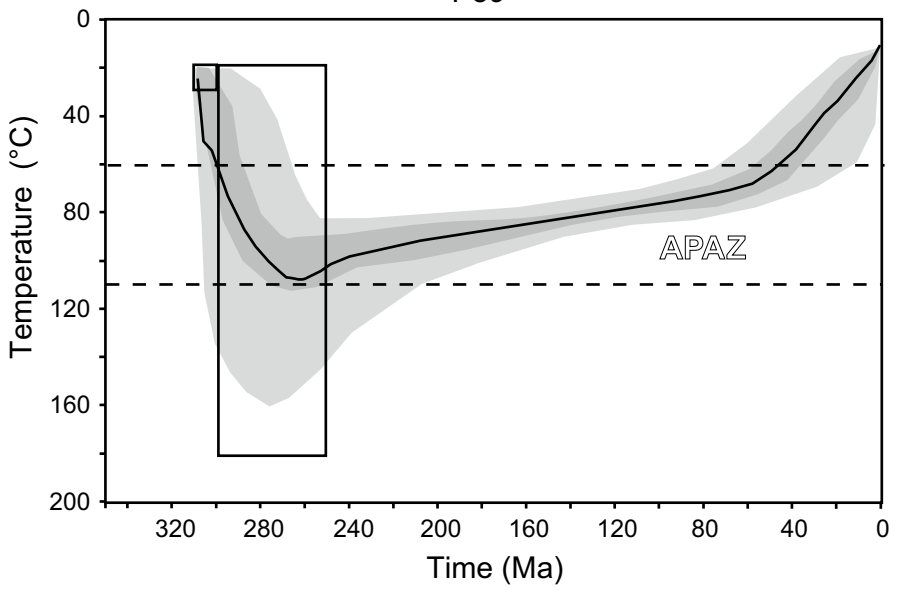

P89

$\mathrm{N}: 94$ confined tracks Age

Model $141 \mathrm{Ma}$

Measured $140.8 \mathrm{Ma}$

GOF 0.97

Length

Model $13.2 \mu \mathrm{m}$

Measured $13.0 \mu \mathrm{m}$

GOF 0.85

$\operatorname{Rr} 0.91 \%$ (s.d. 0.05)

Tmax $1108^{\circ} \mathrm{C}$

Tmax $2126^{\circ} \mathrm{C}$

Tmax3 $140^{\circ} \mathrm{C}$ in order to check the possible influence of the Cretaceous heating being caused by burial, which can be connected with the Albian-Santonian sedimentary cover (Evers 1967) that has been documented at the western end of the Sabero Coalfield (Fig. 1). Assuming an average geothermal gradient of $28{ }^{\circ} \mathrm{C} / \mathrm{km}$ (Fernández et al. 1998) and a sedimentary sequence of a maximum of $800 \mathrm{~m}$ thick, the expected increase in the temperature could be expected to be about $22{ }^{\circ} \mathrm{C}$ during the Late Cretaceous. But the calculated thermal models assuming Cretaceous heating are very similar to the models depicted in Fig. 3; therefore, they are not shown. The temperature of the Stephanian rocks was probably much lower than $60{ }^{\circ} \mathrm{C}$ in Cretaceous times, because the possible Cretaceous heating did not influence these 
Stephanian rocks. Therefore, it seems that it was unlikely that the Stephanian rocks were covered by Cretaceous sediments in most of the area of the Sabero Coalfield. AFT data from the neighbouring Cinera-Matallana Coalfield, $14 \mathrm{~km}$ west of Sabero, (Carrière 2006) suggest that the palaeotemperature of the Stephanian rocks slightly increased in Cretaceous times. This suggestion was not confirmed by our samples from the Sabero Coalfield (Fig. 3). A single heating event calculated by the thermal modelling agrees with the unimodal track length distribution (Fig. 1). Rather low mean track lengths (Table 4) confirm a relatively long stay in the APAZ, which is also visible in the thermal modelling results (Fig. 3). The Permian heating phase in the Sabero Coalfield (Fig. 3) was probably caused by the well-known magmatism and its associated hydrothermal activity under an extensional tectonic regime (Aller et al. 2005; GarcíaLópez et al. 1997, 2007). The important heating phase had a significant thermal effect due to a deep source of heat. The post-Permian cooling is consistent with both the (1) major exhumation after the Late Variscan basin inversion and (2) cooling after a high heat flow regime related to magmatism and hydrothermal activity in Permian times.

All the analysed samples showed that a relatively slow cooling occurred in Mesozoic times, after the Late Carboniferous-Permian heating (Fig. 3). They also indicated an increase in the cooling rate from the Tertiary up to the present day (Fig. 3), which is consistent with the Cainozoic uplift of the Cantabrian Mountains and the last phase of erosion (Alonso et al. 1995). The enhanced exhumation in the last 20-40 Ma is also supported by the cooling pattern in other parts of the Variscan basement (Barbero et al. 2001, 2002, 2005).

The irregular thermal maturity pattern in the Sabero Coalfield (Botor 2012) may reflect the influence of underlying magmatic intrusions (sills and dykes) and hydrothermal-fluid migration, or it could also be related to movements by faults. Stratigraphic and sedimentological analysis of the Stephanian coalfields in the SCZ indicates that they probably represent part of a wider single depositional basin (Heward 1978; Wagner and Winkler-Prins 1985; Knight et al. 2000). A totally eroded overburden related to coalification of the Stephanian rocks was deposited in the Late Stephanian or perhaps also in the Permian. The Permian overburden is indicated only by existence of the Permian age deposits in small basins localized in the area north of the Sabero Coalfield (Martinez-Garcia 1981; Suárez-Rodrigues 1988). The thickness of the eroded Palaeozoic strata in the study area did not exceed $1600 \mathrm{~m}$, according to calculations based on $R_{\mathrm{r}}$ data (Botor 2012). The subsidence rate in the Sabero basin was high ( $\sim 500-700 \mathrm{~m} / \mathrm{Ma})$, considering that approximately $2 \mathrm{~km}$ thickness of sediments remain up to the present day and the depositional period of around 3-4 million years. The additional sedimentary burial $(\sim 1600 \mathrm{~m})$ in the Late Carboniferous or Permian might have caused a temperature increase in about $80{ }^{\circ} \mathrm{C}$, assuming a geothermal gradient of $52{ }^{\circ} \mathrm{C} / \mathrm{km}$ (Botor 2012). Taking into account the surface temperature during the Stephanian sedimentation of $\sim 25{ }^{\circ} \mathrm{C}$ and the above mentioned temperature increase in about $80{ }^{\circ} \mathrm{C}$, the temperature in the analysed Stephanian rocks could increase only up to $105^{\circ} \mathrm{C}$, whilst the temperature calculated from $R_{\mathrm{r}}$ in samples in the study area was $\sim 130-180{ }^{\circ} \mathrm{C}$ (Fig. 3). Therefore, it is evident that burial maximum temperature alone was too low to increase the temperature to the level recorded by $R_{\mathrm{r}}$. This line of evidence allows us to assume that the high Late Carboniferous-Permian heat flow was likely to have been controlled by magmatic events and related hydrothermal activity. The variability amongst the Permian part of the time-temperature paths (heating period, Fig. 3) may be attributed to a fault-delivered differential hydrothermal-fluid circulation coeval with the final stages of the oroclinal-bending-triggered lithospheric delamination (Gutierrez-Alonso et al. 2004) and/or extensional collapse (e.g. Martinez-Catalan et al. 1997) in the north-western Iberian Peninsula. The thermal history of the Sabero Coalfield seems to be related mainly to localized heat redistribution attributed to fault activity. Taking into account the above facts, it seems that the primary Stephanian burial-related coalification pattern was likely to have been overprinted by a fluid flow event, which is supposed to have occurred in Permian times.

\section{Conclusions}

Apatite fission track central ages from the Carboniferous (Stephanian) tonsteins in the Sabero Coalfield range from $140.8 \pm 7.5$ (Early Cretaceous) to $65.8 \pm 8.1 \mathrm{Ma}$ (Late Cretaceous), indicating substantial post-depositional annealing. These results indicate that the Stephanian rocks were heated to temperatures above $110^{\circ} \mathrm{C}$, which is sufficient to totally anneal AFTs. This finding is in accordance with the moderate to high levels of thermal maturity of the organic matter $\left(0.9-1.2 \% R_{\mathrm{r}}\right)$ within these rocks. The unimodal track length distributions, the relatively short mean track length (12.5-13.4 $\mu \mathrm{m}$ for $c$-axis projected track length), and the rather low SD $(1.0-1.6 \mu \mathrm{m})$ indicate a thermal history that could be related to the post-late Variscan heating event(s) followed by a prolonged residence in the apatite partial annealing zone. The Late Carboniferous-Early Permian magmatic activity responsible for the high heat flow (Aller et al. 2005), together with the added effect of significant sedimentary burial in the Late Carboniferous (Botor 2012) could account for the resetting of the AFT system in the Sabero Coalfield. The presence of another mechanism such as fault-related hydrothermal 
activity (Ayllon et al. 2003; Aller et al. 2005; Gasparrini et al. 2006; Botor 2012; Frings and Warr 2012) appears to have been the factor that could have redistributed the heat in areas of significant subsidence and sedimentation, particularly in the vicinity of faults. Thermal modelling using AFT and $R_{\mathrm{r}}$ data has shown that the coalification of organic matter contained in the Stephanian rocks occurred in the Permian, since rather lower palaeotemperatures are indicated for the Mesozoic-Cainozoic period. The postPermian thermal history does not appear to have any influence on the maturation of the Stephanian organic matter. Finally, exhumation and associated erosion rates may possibly have been faster in the Tertiary, causing the present exposure of the studied rocks.

Acknowledgments We would like to express our gratitude to the reviewers, Dr. A. Vamvaka and the Anonymous Reviewer, for their very valuable input, which significantly improved the quality of the paper. Prof. A. Carter (University College London, UK) and Prof. J. Golonka (AGH Kraków, Poland) are thanked for improving the English of the manuscript. We would like to thank Dr. I. Dunkl (Goettingen University, Germany) for his help and for the discussion allowing to understand the fission track data and the modelling procedures. D.B. would like to thank Dr. J.A. Knight for access to tonstein samples from the Sabero Coalfield and for the introduction to the regional geology of the Sabero basin, Prof. C. Brime (Oviedo University, Spain) for productive discussions and detailed maps of the Southern Cantabrian Zone, and Prof. B. Kwiecińska (AGH, Kraków) for her continuous help and support, and for reading an earlier version of the manuscript. This project was partially financed by the Polish Ministry of Science under Grant No. 2307/T02/2007/32 (AGH No. 18.18.140.542) and AGH internal project no. 10.10.140.153.

Open Access This article is distributed under the terms of the Creative Commons Attribution License which permits any use, distribution, and reproduction in any medium, provided the original author(s) and the source are credited.

\section{References}

Aller J, Valin ML, García-López S, Brime C, Bastida F (2005) Superposition of tectono-thermal episodes in the southern Cantabrian Zone (foreland thrust and fold belt of the Iberian Variscides, NW Spain). Bull Soc Geol Fr 176:487-497

Alonso JL (1989) Sintesis cartographica de la region del Manto del Esla. Trabajos de Geologia, vol 18. Univ de Oviedo, Oviedo, pp 155-163

Alonso JL, Pulgar JA, Garcia-Ramos JC, Barba P (1995) Tertiary basins and alpine tectonics in the Cantabrian Mountains (NW Spain). In: Friend PF, Dabrio CJ (eds) Tertiary basins of Spain. Cambridge University Press, Cambridge, pp 214-227

Arne D, Zentilli M (1994) Apatite fission track thermochronology integrated with vitrinite reflectance-a review. In: Mukhopadhyay PK, Dow WG (eds) Vitrinite reflectance as a maturity parameter: applications and limitations, vol 570. American Chemical Society Symposium Series, Washington, pp 249-268

Ayllon F (2003) Mineral, fluid and thermal evolution in veins from late orogenic coal basins of the Cantabrian Zone (Variscan, NW Spain). $\mathrm{PhD}$ dissertation, Heidelberg University, Germany
Ayllon F, Bakker RJ, Warr LN (2003) Re-equilibration of fluid inclusions in diagenetic-anchizonal rocks of the Cinera-Matallana coal basin (NW Spain). Geofluids 3:49-68

Barbarand J, Carter A, Wood I, Hurford T (2003) Compositional and structural control of fission track annealing in apatite. Chem Geol 198:107-137

Barbero L, Lopez Garrido AC, Garcia-Hernandez M, Quesada S, Martinez del Olmo W (2001) Evolucion termal mesozoica de la Cuenca Prebetica (Sierra de Segura) inferida mediante analisis de huellas de fision en apatito: resultados preliminares. Geotemas 3(2):155-160

Barbero L, Lopez Garrido AC, Garcia Hernandez M, Quesada S (2002) Thermal history of the prebetic platform: constraints from apatite fission track data. Geotemas 4:23-26

Barbero L, Glasmacher UA, Villaseca C, López-García JA, MartínRomera C (2005) Long-term thermo-tectonic evolution of the Montes de Toledo area (Central Hercynian Belt, Spain): constraints from apatite fission track analysis. Int J Earth Sci 94:193-203

Barker C, Pawlewicz MJ (1994) Calculation of vitrinite reflectance from thermal histories: a comparison of methods. In: Mukhopadhyay PK, Dow WG (eds) Vitrinite reflectance as a maturity parameter: applications and limitations, vol 570. American Chemical Society Symposium Series, Washington, pp 216-229

Bastida F, Brime C, García-López S, Sarmiento GN (1999) Tectonothermal evolution in a region with thin-skinned tectonics; the western nappes in the Cantabrian Zone (Variscan Belt of NW Spain). Int J Earth Sci 88:38-48

Botor D (2005) Geochemistry of Stephanian tonsteins from the Sabero Coalfield (NW Spain). Geol Trans Sil Univ Technol 268:19-30

Botor D (2011) Trace element geochemistry of coals from the Southern Cantabrian Zone (NW Spain): preliminary results. Mineralogia 42:39-51

Botor D (2012) Hydrothermal fluids influence on the thermal evolution of the Stephanian sequence, the Sabero Coalfield (NW Spain). Geol Geophys Environ 38:369-393

Botor D, Toboła T, Morga R, Komorek J (2009) Thermal evolution of the Sabero Coalfield (NW Spain): evidence from coal optical anisotropy and fluid inclusions. Documenta Geonica, Ostrava, Czech Republic 2:17-22

Braun J, Van der Beek P, Batt G (2008) Quantitative thermochronlogy. Cambridge University Press, Cambridge

Bray RJ, Green PF, Duddy IR (1992) Thermal history reconstruction using apatite fission track analysis and vitrinite reflectance: a case study from the UK East Midlands and Southern North Sea. In: Hardman RF (ed) Exploration Britain: geological insights for the next decade, vol 67. Geological Society Special Publication, London, pp 3-25

Brime C, García-López S, Bastida F, Valin ML, Sanz-Lopez J, Aller J (2001) Transition from diagenesis to metamorphism near the front of the Variscan regional metamorphism (Cantabrian Zone, NW Spain). J Geol 109:363-379

Burtner RL, Nigrini A, Donelick RA (1994) Thermochronology of lower cretaceous source rocks in the Idaho-Wyoming thrust belt. Bull Am Assoc Petrol Geol 78:1613-1636

Carrière KL (2006) Neoproterozoic to Holocene tectonothermal evolution of the southern Cantabrian Mountains NW Iberia, revealed by apatite fission track thermochronology. PhD dissertation, Heidelberg University

Colmenero JR, Prado JG (1993) Coal basins in the Cantabrian Mountains, NW Spain. Int J Coal Geol 23:215-229

Colmenero JR, Suárez-Ruiz I, Fernández-Suárez J, Barba P, Llorens $\mathrm{T}$ (2008) Genesis and rank coal basins in the Cantabrian Mountains, NW Spain. Int J Coal Geol 23:215-229 
Copard Y, Disnar JR, Becq-Giraudon JF, Boussafir M (2000) Evidence and effects of fluid circulation on organic matter in intramontane coalfields (Massif Central, France). Int J Coal Geol 44:49-68

Dallmeyer RD, Martínez-Catalán J, Arenas R, Gillbarguchi JI, Gutiérrez-Alonso G, Farias P, Bastida F, Aller J (1997) Diachronous Variscan tectonothermal activity in the NW Iberian Massif: evidence from ${ }^{40} \mathrm{Ar} /{ }^{39} \mathrm{Ar}$ dating of regional fabrics. Tectonophysics 277:307-337

Donelick RA, Ketcham RA, Carlson WD (1999) Variability of apatite fission track annealing kinetics: II. Crystallographic orientation effects. Am Mineral 84:1224-1234

Donelick RA, O'Sullivan PB, Ketcham RA (2005) Apatite fission track analysis. Rev Miner Geochem 58:49-94

Duddy IR, Green PF, Bray RJ, Hegarty KA (1994) Recognition of the thermal effects of fluid flow in sedimentary basins. In: Parnell $\mathrm{J}$ (ed) Geofluids: origin, migration and evolution of fluids in sedimentary basins, vol 78. Geological Society London Special Publications, London, pp 325-345

Dumitru T (1993) A new computer-automated microscope stage system for fission track analysis. Nucl Tracks Radiat Meas 21:575-580

Dunkl I (2002) Trackkey: a Windows program for calculation and graphical presentation of fission track data. Comput Geosci 28:3-12

Evers HJ (1967) Geology of the Leonides between the Bernesga and Porma Rivers, Cantabrian Mts. Spain. Leidse Geol Mededelingen 44:81-151

Fernández M, Marzan I, Correia A, Ramalho E (1998) Heat flow, heat production, and lithospheric thermal regime in the Iberian Peninsula. Tectonophysics 291:29-53

Fernández-Suárez J, Dunning GR, Jenner GA (2000) Variscan collisional magmatism and deformation in NW Iberia: constrains form U-Pb geochronology of granitoids. J Geol Soc Lond 157:565-576

Frings KH, Warr LN (2012) Hydrothermally altered mudrock of the Cinera-Matallana coal basin, Cantabrian Zone, Northern Spain. Eur J Mineral 24:1017-1029

Frings U, Lutz R, de Wall H, Warr LN (2004) Coalification history of the Cinera-Matallana pull-apart basin (NW Spain): combining anisotropy of vitrinite reflectance and thermal modelling. Int J Earth Sci 93:92-106

Galbraith RF (1981) On statistical models of fission track counts. Math Geol 13:471-478

Galbraith RF (1990) The radial plot: graphical assessment of spread in ages. Nucl Tracks Radiat Meas 17:207-214

Galbraith RF, Laslett GM (1993) Statistical models for mixed fission track ages. Nucl Tracks Radiat Meas 21:459-470

Gallhager K, Carter A, Johonson J (1998) Fission track analysis: method and its applications. Earth-Sci Rev 17:52-87

García-López S, Brime C, Bastida F, Sarmiento GN (1997) Simultaneous use of thermal indicators to analyse the transition from diagenesis to metamorphism: an example from the Variscan Belt of NW Spain. Geol Mag 134:323-334

García-López S, Brime C, Valin ML, Sanz-Lopez J, Bastida F, Aller J, Blanco-Ferera S (2007) Tectonothermal evolution of a foreland fold and thrust belt: the Cantabrian Zone, Iberian Variscan Belt, NW Spain. Terra Nova 19:469-475

Gasparrini M, Bakker R, Bechstädt T, Boni M (2003) Hot dolomites in a Variscan foreland belt: hydrothermal flow in the Cantabrian Zone (NW Spain). J Geochem Explor 78(79):501-507

Gasparrini M, Bechstädt T, Boni M (2006) Massive hydrothermal dolomite in the southwestern Cantabrian Zone (Spain) and its relation to the late Variscan evolution. Mar Pet Geol 23:543-568
Gleadow AJW, Duddy IR, Green PF, Lovering JF (1986) Confined fission track lengths in apatite: a diagnostic tool for thermal history analysis. Contrib Miner Petrol 94(405):415

Gómez-Fernández F, Both RA, Mangas J, Arribas A (2000) Metallogenesis of $\mathrm{Zn}-\mathrm{Pb}$ carbonate-hosted mineralisation in the SE region of the Picos de Europa (Northern Spain) province: geologic, fluid inclusion and stable isotope studies. Econ Geol 95:19-40

Green PF (1986) On the thermo-tectonic evolution of Northern England: evidence from fission track analysis. Geol Mag 123:493-506

Grobe R, Alvarez J, Glasmacher UA, Menendez R (2010) Low-temperature exhumation history of Variscan-age rocks in the western Cantabrian Mountains (NW Spain) recorded by apatite fission track data. Tectonophysics 499:76-90

Gutierrez-Alonso G, Fernández-Suárez J, Weil AB (2004) Orocline triggered lithospheric delamination. Geol Soc Am Spec Pap 383:121-131

Heward AP (1978) Alluvial fan and lacustrine sediments from the Stephanian A and B (La Magdalena, Sabero and Cinera-Matallana coalfields) NW Spain. Sedimentology 25:451-488

Heward AP, Reading HG (1980) Deposits associated with a Hercynian to late Hercynian continental strike-slip system, Cantabrian Mountains, Northern Spain. Int Assoc Sedimentol 4:105-125

Hu S, O'Sullivan PB, Raza A, Kohn BP (2001) Thermal history and tectonic subsidence of the Bohai Basin, China: a Cenozoic rifted and local pull-apart basin. Phys Earth Planet Inter 126:221-235

Hurford AJ (1990) Standardization of fission track dating calibration: recommendations by the Fission Track Working Group of the I.U.G.S. Subcommission on Geochronology. Chem Geol 80:171-178

Hurford AJ, Green PF (1983) The zeta age calibration of fission track dating. Chem Geol 41:285-312

International Organization for Standardization (ISO) (1994) Methods for the petrographic analysis of bituminous coal and anthracitepart 5: methods determining microscopically the reflectance of vitrinite. ISO 7404-5, Geneva, Switzerland, p 11

Juez-Larré J, Ter Voorde M (2009) Thermal impact of the break-up of Pangea on the Iberian Peninsula, assessed by thermochronological dating and numerical modelling. Tectonophysics 474:200-213

Julivert M (1971) Décollement tectonics in the Hercynian Cordillera of NW Spain. Am J Sci 270:1-29

Ketcham RA (2005) Forward and inverse modeling of low-temperature thermochronometry data. Rev Miner Geochem 58:275-314

Ketcham RA, Donelick RA, Donelick MB (2000) AFTSolve: a program for multi-kinetic modeling of apatite fission track data. Geol Mat Res 2:1-32

Ketcham RA, Carter A, Donelick RA, Barbarand J, Hurford AJ (2007a) Improved measurement of fission track annealing in apatite using $c$-axis projection. Am Mineral 92:789-798

Ketcham RA, Carter A, Donelick RA, Barbarand J, Hurford AJ (2007b) Improved modelling of fission track annealing in apatite. Am Mineral 92:799-810

Knight JA (1983) The stratigraphy of the Stephanian rocks of the Sabero Coalfield, NW Spain. Paleontographica Abt B Bd 187:1-89

Knight JA, Burger K, Bieg G (2000) The pyroclastic tonsteins of the Sabero Coalfield, north-western Spain, and their relationship to the stratigraphy and structural geology. Int J Coal Geol 44:187-226

Lobato L, Garcia Alcalde JL, Sánchez de Posada LC, Truyols J, Villegas FJ (1984) Hoja del Mapa Geológico Nacional E. 1:50.000 $\mathrm{n}^{\circ} 104$ (Bońar). 2 Serie MAGNA. Instituto Geológico y Minero de Espańa, Madrid 
Lopez-Gomez J, Arche A, Pérez-López A (2002) Permian and Triassic. In: Gibbons W, Moreno T (eds) The geology of Spain. The Geological Society, London, pp 185-212

Luque C, Martínez-García E, Ruiz F (1990) Metallogenesis. In: Dallmeyer RD, Martínez-García E (eds) Pre-Mesozoic geology of Iberia. Springer, Berlin, pp 80-87

Marcos A, Pulgar JA (1982) An approach to the tectonostratigraphic evolution in the Cantabrian Foreland thrust and fold belt, Hercynian Cordillera of NW Spain. Neues Jahrbuch Geol Paläontologie 163(2):256-260

Martinez-Catalan JR, Arenas R, Díaz-García F, Abati J (1997) Variscan accretionary complex of NW Iberia: terrane correlation and succession of tectonothermal events. Geology 25:1103-1106

Martinez-Garcia E (1981) El Paleozoico de la Zona Cantabrica Oriental. Trabajos de Geologia 11:95-127

Martin-Gonzalez F, Barbero L, Capote R, Heredia N, Gallastegui $G$ (2012) Interaction of two successive Alpine deformation fronts: constraints from low-temperature thermochronology and structural mapping, NW Iberian Peninsula. Int J Earth Sci 101:1331-1342

Mendez CAF (1985) Estudio de la evolucion de los carbones de la cuenca Cinera-Matallana, Leon. PhD dissertation, Oviedo University, Spain

Munoz M, Anchoca E, Sagredo J, Hernan F, Brandle J. Marfil R (1985) Vulcanismo Permo-Carbonifero de la Cordillera Iberica. In: 10th Congress Carbonifere, Madrid 1983, pp 27-52

Pérez-Estaún A, Bastida F, Alonso JL, Marquinez J, Aller J, AlvarezMarrón J, Marcos A, Pulgar JA (1988) A thin-skinned tectonics model for a fold and thrust belt of the Cantabrian Zone. Tectonics 7(3):517-537

Reading HG (1975) Strike-slip fault systems: an ancient example form the Cantabrians (Spain). In: IX International Congress of Sedimentology, Nice, Theme 4(2):287-292

Reicherter KR, Pletsch TK (2000) Evidence of a synchronous circum-Iberian subsidence event and its relation to the
African-Iberian plate convergence in the Late Cretaceous. Terra Nova 12:141-147

Sachsenhofer RF (2001) Syn- and post-collisional heat flow in the Cenozoic Eastern Alps. Int J Earth Sci 90:579-592

Schneider J, Bakker RJ, Bechstadt T, Littke R (2008) Fluid evolution during burial diagenesis and subsequent orogenic uplit: the La Vid Group (Cantabrian Zone, Northern Spain). J Sediment Res 78:282-300

Schwentke W, Kuhnt W (1992) Subsidence history and continental margin evolution of the western Pyrenean and Basque basins. Palaeogeog Palaeoclimatol Palaeoecol 95:297-318

Suárez-Rodrigues A (1988) Estructura del area de Villaviciosa-Libardon (Asturias, Cordilliera Cantabrica). Trabajos de Geologia 17:87-98

Sweeney JJ, Burnham AK (1990) Evaluation of a model of vitrinite reflectance based on chemical kinetics. AAPG Bull 74:1559-1570

Van Der Voo R, Stamatakos JA, Pares JM (1997) Kinematic constraints on thrust-belt curvature from syndeformational magnetization in Lagos de Valle Syncline in the Cantabrian Arc, Spain. J Geophys Res 102:105-120

Wagner RH, Winkler-Prins CF (1985) The Cantabrian and Barruelian stratotypes: a summary of basin development and biostratigraphic information. In: Lemos de Sousa MJ, Wagner RH (eds) Papers on the Carboniferous of the Iberian Peninsula, vol 64. Anais da Facultade de Ciencias, Universidade do Porto, Porto, pp 359-410

Weil AB, Van Der Voo R, Van Der Pluijm BA, Pares JM (2001) Oroclinal bending and evidence against the Pangea megashear: the Cantabria-Asturias arc (northern Spain). Geology 29:991-994

Weil AB, Gutiérrez-Alonso G, Conan J (2010) New time constraints on lithospheric-scale oroclinal bending of the Ibero-Armorican arc: a palaeomagnetic study of earliest Permian rocks from Iberia. J Geol Soc London 167:127-143 